\title{
Music Education Effect on Improving Students' Comprehensive Quality
}

\author{
Qi Li \\ Linyi University, Shandong 273400, China. \\ 11703845@qq.com
}

\begin{abstract}
Since the 1990s, cultivating the students' comprehensive ability has drawn attention from the society widely. On May 15, 1999, comrade Jiang Zemin made a speech on the third national education workshop in which he emphasized that, "We must comprehensively implement the educational policy of the party, persisting that education serves for the socialism and the people, persisting that education combines with the social practice, taking improving our national quality as our basic objective, focusing on improving students' innovative spirit and the practice ability, diligently molding our students as having ideal, having morals, having knowledge and having discipline, making their moral, intellectual, physical and esthetic ability develop fully, making them as our socialism constructor and successor". Therefore, improving students' comprehensive qualities becomes one of the essential targets of cultivating high-quality students.
\end{abstract}

Keywords: Music education; students' comprehensive quality.

\section{Background}

However, the actual effect and the present situation of cultivating our students' comprehensive ability in our country is not so satisfying, there's a saying "gigantic education for all-around development, solid education for the examinations". Comrade Deng Xiaoping once incisively pointed out that, "Since the reform and open policy, our biggest fault has been in the education aspect". The long-term education system had decided that our education had put excessive efforts in intellectual instruction but neglected the moral and the esthetic aspects. Thus, in this kind of situation, raising students' comprehensive quality needs to be solved in other angle of view. Music is a kind of art which displays emotion, and is the important constituent of education for all-around development, music education plays an important role which cannot be substituted in the consummation of personality, purification one's mind and promoting students' comprehensive quality.

\section{Introduction}

Music is a form of performance art. It is through the music organized by the formation of art forms to express the thoughts and feelings of the people, reflecting the social reality of life. Music education is people-oriented with the aesthetic as the core. It is one of the important means of the implementation of aesthetic education, but also an important part of the comprehensive quality of students.

\subsection{The Meaning of Music Education.}

Music education is a kind of educational practice. Music education reflects the social politics and economy. It restricted by a certain level of social economy and the development of product. It services for basic economic with the superstructure properties. Music education is a product of the development of mankind itself, and it is also a kind of social cultural phenomenon. At the same time, music education is to cultivate people's social practice activities. The music education is to cultivate human, especially in children and young people as the key object of educational activities.

\subsection{The Essential Characteristics of Education.}

Music education belongs to art education, music education is a kind of unique artistic beauty, and also has the function of aesthetic education in the perfect national education mechanism. The whole process of music education should be reflected in the process of educating people with aesthetic appreciation as the core. Music education has the following characteristics: 
(1) People oriented

German music educator Karl Orff said, "Music begins from within itself." Modern emerging disciplines of Anthropology of music, from the angle of anthropology to explore the music of the nature, origin and understanding to music feeling is natural, music and dance, art is the human nature, the nature. Anthropology of music is a modern discipline, from the angle of anthropology to discuss the music of the nature, origin and understanding the music feeling is natural. Music and dance is the human nature arts. The music is indispensable to people objectively, humans have inherent demand for music. It takes people's life consciousness as the center, reflects the person's essence, displays the human mind, and molds the personality.

(2) Aesthetics-centered

Music learning and a variety of music activities mobilize the music aesthetic ability of music aesthetic experience under control of the aesthetic needs of the music and the regulation of music aesthetic consciousness. The music education of music aesthetic ability cultivation is refers to the music education cultivates auditory sense of music perception, music association and imagination ability, music emotional feelings, comprehension and expression.

\subsection{The Meaning of Student's Comprehensive Quality.}

Quality originally used in Darwin's evolution theory. It is refers to the species formed in the "natural selection" competition for survival and evolution process of the function. After nineteenth Century, with the development of modern natural science, genetics, physiology, psychology and other disciplines and people have inherited the biological characteristics of the ancestors, known as the genetic quality. Since then, in the social life and the modern school education activities, the quality has been widely adopted by the application. It becomes a concept with a variety of meanings.

\subsection{The Contents of Student's Comprehensive Quality.}

What is the content of the comprehensive quality of students, the academic view is different. Some people believe that the comprehensive quality of students include political theory quality, ideological and moral quality, cultural and scientific quality, professional quality, physical and psychological quality, etc [1]. It is also believed that the comprehensive quality can be divided into three basic qualities: physical quality, intellectual quality (IQ) and non intellectual quality (EQ). According to the requirement of the current social development, the comprehensive quality of the students mainly includes the following aspects:

(1) Ideological and moral quality

At present, the ideological and moral quality of the students mainly consists of three aspects: ideological quality, political quality and moral quality.

Ideological quality is the theoretical accomplishment of students to receive education, master the scientific world outlook and methodology of Marx's doctrine. Political quality of students is the attitude of the party, state, constitution and the socialist system under the action of the ideological quality. It exhibits different degree of political stand, political orientation, and political views. The moral quality is students consciously abide by the social moral quality in social life. It is the cognition and practice of the socialist moral reflection.

(2) Scientific and cultural quality

The scientific and cultural quality refers to the students have a comprehensive knowledge structure and intelligent structure, at the same time they have a high quality of civilization and artistic accomplishment. It includes four parts: basic knowledge, basic skills, ability of observation, imagination, thinking, learning, research and creation, and the ability of aesthetic appreciation and creation of the beauty.

(3) Psychological quality

The psychological quality is based on the physical condition, and internalized the external things into a stable, basic and derivative, and the psychological quality which is closely related to the human's social adaptive behavior and the creative behavior [2]. 
(4) Physical quality

Physical quality of students not only have a healthy body and full of spirit, perseverance, stamina and resilience, agile thinking and a good memory, but also good health habits and patterns of life and so on.

\section{Music Education Plays an Important Role in Students' Comprehensive Quality}

The survey shows that $67 \%$ students love music, $28 \%$ students like music, only $5 \%$ students don't like music, no one complete dislike music. The percentage of students who like the kinds of music are shown in figure 1 and table 1.

Table 1 students who like the kinds of music

\begin{tabular}{|c|c|c|c|c|c|c|c|c|}
\hline $\begin{array}{c}\text { The type of } \\
\text { music }\end{array}$ & $\begin{array}{c}\text { Western } \\
\text { classical } \\
\text { music }\end{array}$ & $\begin{array}{c}\text { Chinese } \\
\text { National } \\
\text { Music }\end{array}$ & $\begin{array}{c}\text { Light } \\
\text { music }\end{array}$ & Jazz & Rock & $\begin{array}{c}\text { Popular } \\
\text { music }\end{array}$ & $\begin{array}{c}\text { Dance } \\
\text { music }\end{array}$ & Summation \\
\hline numbers & 49 & 26 & 23 & 20 & 16 & 109 & 5 & 248 \\
\hline percentage & $19.76 \%$ & $10.48 \%$ & $9.27 \%$ & $8.06 \%$ & $6.45 \%$ & $43.95 \%$ & $2.03 \%$ & $100 \%$ \\
\hline
\end{tabular}

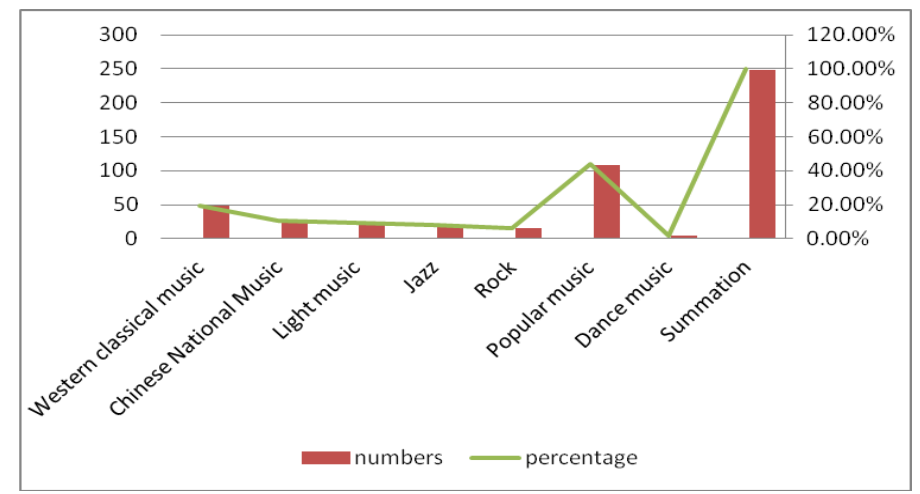

Figure 1 students who like the kinds of music

As can be seen from the table, the most of students are love music. The music is beneficial for students' comprehensive quality. There are some benefits as follows.

\subsection{The Music Education Effect on the Cultivation of Students' Ideological and Moral Quality.}

The students have little experience, so they easily affected by incorrect ideas and unhealthy lifestyle. Music education in a subtle influence on the students' sentiment, purify the students' mind, improve students' ideological level.

The relationship between music and ideological and moral education is very close. Music is a form of thought and art. It contains a profound meaning of the true, the good and the beautiful. It through arts expresses their true emotion and people's lofty moral sentiments and thoughts and feelings. Music to its superb artistic image, heartfelt good feelings, knock people mind, edify sentiment to improve people's spiritual realm and inspire people to strive.

\subsection{The Music Education Effect on the Cultivation of Students' Cultural Quality.}

Music education is conducive to improve the student's intelligence, development of students' thinking in images, balance and adjust the two hemispheres of the brain function and promote brain development. So as to promote the perfection of human intelligence and better master the scientific knowledge. Music education is conducive to the cultivation of students' imagination and creativity and helps to improve students' artistic accomplishment and aesthetic appreciation.

\subsection{The Music Education Effect on the Cultivation of Students' Psychological Quality.}

The contemporary concept of health refers to both physical and psychological states. The students are in adolescence, the development of physiology and psychology will be unbalanced, unstable and falling. Music education helps to improve students' psychological quality. Music education is to cultivate people's psychological and mental health as the goal. Music education makes students have the correct psychological frustration, better psychological balance and self-control ability. They often 
enjoy good music works can effectively suppress the bad desire and impetuous, and to develop a good emotional experience, purify the soul.

\subsection{The Music Education Effect on the Cultivation of Students' Physical Quality.}

The relationship between music and sports is very close. The purpose of sports is to enhance people's physical fitness, promote physical health. So that people have a good speed, endurance, strength, skill, well-developed muscles and symmetrical shape. The rhythm of music is helpful to the coordination of the body movements, the body's flexibility and fitness. Sports with music can enhance the health and beauty of the infection.

\section{Conclusion}

The importance of music education is to fully affirm the special status and important role of art education in the quality education of students, and even the whole national quality education. To strengthen music education in ordinary colleges and universities, it improves the students' aesthetic experience, helps to stimulate students a variety of perceptual and cognitive ability. It is helpful to cultivate students a wealth of imagination, expression and creativity.

\section{References}

[1] Huang Jiusi. The Philosophical Reflection on the Comprehensive Quality of College Students[J]. Hunan Social Sciences, 2013(02).

[2] Zhang Dajun, Feng Zhengzhi. A Few Question about Psychological quality of College Students[J]. Journal of Southwest China Normal University, 2000(03).

[3] Lu Zhida. The Importance of Music Education in the Quality Education of Students[J]. Art Science and Technology, 2014(5): 363-364.

[4] R Crawford. Evolving Technologies Require Educational Policy Change: Music Education for the 21st Century[J]. Australasian Journal of Educational Technology, 2013, 29(5):717-734.

[5] D Gillies, A Kennedy, T Bryce, W Humes. Music Education[J]. Edinburgh University Press, 2014.

[6] ER Jorgensen. Values and Philosophizing about Music Education[J]. Philosophy of Music Education Review, 2014, 22(1):5-21. 